\title{
Updated $\mathrm{SO}_{2}$ emission estimates over China using OMI/Aura observations
}

\author{
Maria Elissavet Koukouli ${ }^{1}$, Nicolas Theys ${ }^{2}$, Jieying Ding ${ }^{3,4}$, Irene Zyrichidou ${ }^{1}$, Bas Mijling ${ }^{3}$, Dimitrios Balis ${ }^{1}$, and \\ Ronald Johannes van $\operatorname{der} \mathbf{A}^{3}$ \\ ${ }^{1}$ Laboratory of Atmospheric Physics, Aristotle University of Thessaloniki, Greece \\ ${ }^{2}$ Royal Belgian Institute for Space Aeronomy (BIRA-IASB), Brussels, Belgium \\ ${ }^{3}$ Royal Netherlands Meteorological Institute (KNMI), De Bilt, the Netherlands \\ ${ }^{4}$ Technical University Delft, Delft, the Netherlands
}

Correspondence: Maria Elissavet Koukouli (mariliza@auth.gr)

Received: 20 July 2017 - Discussion started: 27 September 2017

Revised: 29 December 2017 - Accepted: 23 February 2018 - Published: 29 March 2018

\begin{abstract}
The main aim of this paper is to update existing sulfur dioxide $\left(\mathrm{SO}_{2}\right)$ emission inventories over China using modern inversion techniques, state-of-the-art chemistry transport modelling (CTM) and satellite observations of $\mathrm{SO}_{2}$. Within the framework of the EU Seventh Framework Programme (FP7) MarcoPolo (Monitoring and Assessment of Regional air quality in China using space Observations) project, a new $\mathrm{SO}_{2}$ emission inventory over China was calculated using the CHIMERE v2013b CTM simulations, 10 years of Ozone Monitoring Instrument (OMI)/Aura total $\mathrm{SO}_{2}$ columns and the pre-existing Multiresolution Emission Inventory for China (MEIC v1.2). It is shown that including satellite observations in the calculations increases the current bottom-up MEIC inventory emissions for the entire domain studied $\left(15-55^{\circ} \mathrm{N}, 102-\right.$ $132^{\circ} \mathrm{E}$ ) from 26.30 to $32.60 \mathrm{Tg}$ annum ${ }^{-1}$, with positive updates which are stronger in winter $(\sim 36 \%$ increase). New source areas were identified in the southwest $\left(25-35^{\circ} \mathrm{N}\right.$, $\left.100-110^{\circ} \mathrm{E}\right)$ as well as in the northeast $\left(40-50^{\circ} \mathrm{N}, 120\right.$ $130^{\circ} \mathrm{E}$ ) of the domain studied as high $\mathrm{SO}_{2}$ levels were observed by OMI, resulting in increased emissions in the a posteriori inventory that do not appear in the original MEIC v1.2 dataset. Comparisons with the independent Emissions Database for Global Atmospheric Research, EDGAR v4.3.1, show a satisfying agreement since the EDGAR 2010 bottom-up database provides $33.30 \mathrm{Tg}$ annum $^{-1}$ of $\mathrm{SO}_{2}$ emissions. When studying the entire OMI/Aura time period (2005 to 2015), it was shown that the $\mathrm{SO}_{2}$ emissions remain nearly constant before the year 2010, with a drift of
\end{abstract}

$-0.51 \pm 0.38 \mathrm{Tg}$ annum $^{-1}$, and show a statistically significant decline after the year 2010 of $-1.64 \pm 0.37 \mathrm{Tg}$ annum $^{-1}$ for the entire domain. Similar findings were obtained when focusing on the greater Beijing area $\left(30-40^{\circ} \mathrm{N}, 110-120^{\circ} \mathrm{E}\right)$ with pre-2010 drifts of $-0.17 \pm 0.14$ and post- 2010 drifts of

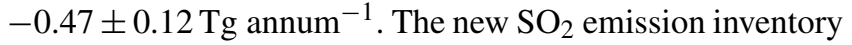
is publicly available and forms part of the official EU MarcoPolo emission inventory over China, which also includes updated $\mathrm{NO}_{x}$, volatile organic compounds and particulate matter emissions.

\section{Introduction}

Due to its undoubtable rapid economic growth, swift urbanization and consequent enlarged energy needs, large parts of China have been suffering from severe and persistent environmental issues including major air pollution episodes (Song et al., 2017). Developing and implementing effective air quality control policies is essential in combating such pollution problems and requires timely as well as dependable information on emission levels (Zhang et al., 2012; van der A et al., 2017). Understanding and monitoring the local long-term trends of different atmospheric pollutants is paramount in updating, and predicting, pollution emission scenarios (Kan et al., 2012). Satellite atmospheric observations have recently become an important information source on the atmospheric state, not only for the academic community but also for public authorities and international environ- 
mental agencies (Streets et al., 2013; Lu and Liao, 2016). Recent reductions of the two major pollutants emitted mainly by industrial sources, nitrogen and sulfur dioxide, have already successfully been observed and quantified from space-born instruments over China (Wang et al., 2010, 2015; Liu et al., 2015, 2017).

Sulfur dioxide, $\mathrm{SO}_{2}$, is released into the atmosphere through both natural and anthropogenic processes. In the former category lie chemical processes, such as the reaction of hydrogen sulfide, which is naturally occurring in crude petroleum and natural gas as well as arising from the breakdown of organic matter, with atmospheric oxygen; seasonal biomass burning events, which may be foreseen to some extent if not modelled; and volcanic degassing and unexpected eruptions (see for example Seinfeld and Pandis, 1998). In the latter category fall the combustion of coal and oil fuel, which account for more than $75 \%$ of global $\mathrm{SO}_{2}$ emissions (Klimont et al., 2013), a figure found to be similar when focusing on the Chinese domain (Smith et al., 2001, 2011). Lu et al. (2011) showed that $\mathrm{SO}_{2}$ emissions over China, calculated from all major anthropogenic sources as well as scheduled biomass burning events by the agricultural sector in order to clear vegetation and rejuvenate croplands, increased from $\sim 24 \mathrm{Tg}$ in 1996 to $\sim 31 \mathrm{Tg}$ in 2010, including fluctuations due to the onset of environmental protection measures as well as the international economic crisis. The balance between encouraging China's economic development and dealing with its environmental side effects often causes irregular changes in the $\mathrm{SO}_{2}$ emitted amounts, further dependent on the province observed.

Satellite $\mathrm{SO}_{2}$ observations have proven to be a reliable way to monitor emissions from space and are increasingly used in order to update bottom-up emission inventories (Streets et al., 2013). Numerous works have already amply demonstrated the ability of satellite sensors to observe regional anthropogenic emission sources, for example by studying the $\mathrm{SO}_{2}$ load over China using Ozone Monitoring Instrument, OMI, Aura observations. Krotkov et al. (2016) have shown how using long-term atmospheric data records from the same instrument (OMI/Aura) can provide consistent spatiotemporal coverage, enabling the analysis of both anthropogenic and natural emissions. For the North China Plain, of direct interest to this work, it was shown that, despite it exhibiting the world's most severe $\mathrm{SO}_{2}$ pollution, since 2011 a decreasing trend with a $50 \%$ reduction in emissions has been verified from space. It is of course not only the changing economy and enforcement of legislation that affect air quality; Witte et al. (2009) calculated a $13 \%$ reduction in sulfur dioxide emissions due to strict pollutant control for the August-September 2008 Olympic and Paralympic Games held in Beijing observed from space. Li et al. (2010) further demonstrated that the OMI/Aura observations are capable of verifying the effectiveness of China's $\mathrm{SO}_{2}$ emission control measures on power plants, while the imbalance in coal consumption between the different provinces in China was also shown by Jiang et al. (2012). This inter-province diversion was further examined in van der A et al. (2017), who showed how provinces enforcing desulfurization devices on their power plants have a decreasing $\mathrm{SO}_{2}$ trend, whereas emerging provinces, which have built new power plants to accommodate the rapid urbanization of the Chinese population, contribute with high emissions to the country's estimates.

Quite recently a new technique has used OMI/Aura observations as a means to detect large point sources of $\mathrm{SO}_{2}$ emissions from diverse origins, presented by Fioletov et al. (2013, 2016). Satellite observations were used not only to identify but also to group $\mathrm{SO}_{2}$ emissions into emissions by volcanoes, power plants, smelters, and the oil and gas industry. The technique has been evolved (Fioletov et al., 2017) into directly assessing traditional statistically obtained emission levels using OMI as well as OMPS/NPP $\mathrm{SO}_{2}$ columns, with excellent validation results.

Following the aforementioned findings, in this work we aim to present a new spatially resolved $\mathrm{SO}_{2}$ emission inventory on a monthly timescale for the years 2005 to 2015 based on satellite observations and modern chemical transport modelling simulations. The technique used here has recently been applied in both Europe (Zyrichidou et al., 2015) and China (Gu et al., 2014) for $\mathrm{NO}_{x}$ emissions based on both GOME/ERS-2 (Global Ozone Monitoring Experiment/second European Remote Sensing satellite) and OMI/Aura observations. We aim to show how it can be applied also to $\mathrm{SO}_{2}$ emissions and how the new top-down emissions compare against traditional bottom-up emission inventories.

\section{Data description}

The mathematical analysis used in this work in order to extract an updated $\mathrm{SO}_{2}$ emission inventory is fully described in Sect. 3. The main gist is that three input pieces of information are required: an original, also known as a priori, emission inventory; the satellite observations of the $\mathrm{SO}_{2}$ load; and $\mathrm{SO}_{2}$ profiles provided by an air quality chemistry transport model. The quality of these three pieces of information ensures the accuracy of the updated, a posteriori, $\mathrm{SO}_{2}$ emissions estimates. Since the mathematical formulism also requires quantifiable error estimates on these three input parameters, using the new OMI/Aura Royal Belgian Institute for Space Aeronomy (BIRA) $\mathrm{SO}_{2}$ dataset (Theys et al., 2015, 2017) ensures that the satellite observations used here are fully characterized in this manner. In Sects. 2.1 to 2.3 the three input datasets are presented and discussed appropriately. 
MEIC emissions $\mid \mathrm{SO}_{2} \mathrm{Mg} /$ month

\section{(a) Industry}

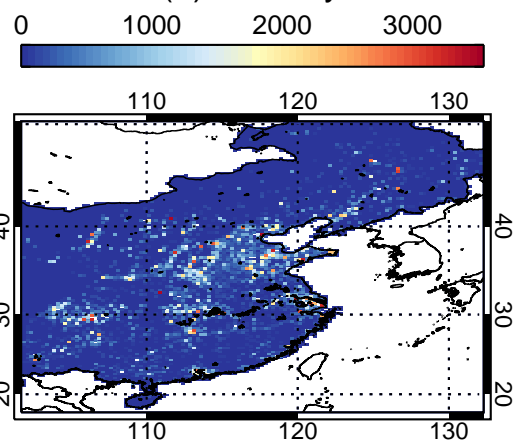

(c) Residential
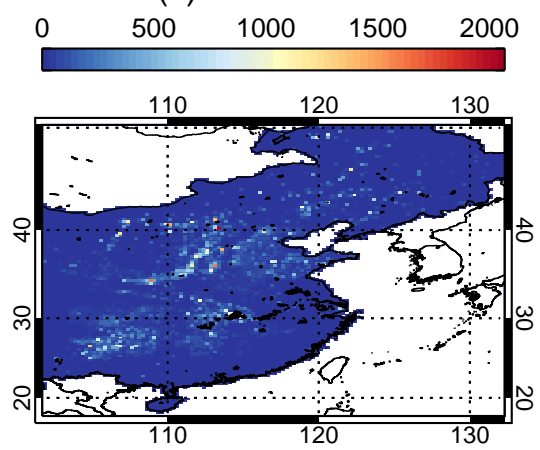

March 2010

(b) Power

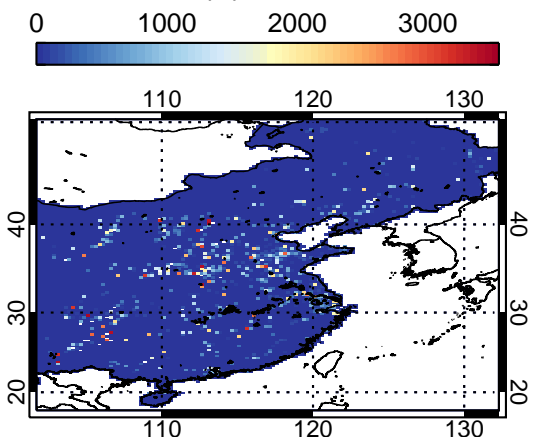

(d) Transportation

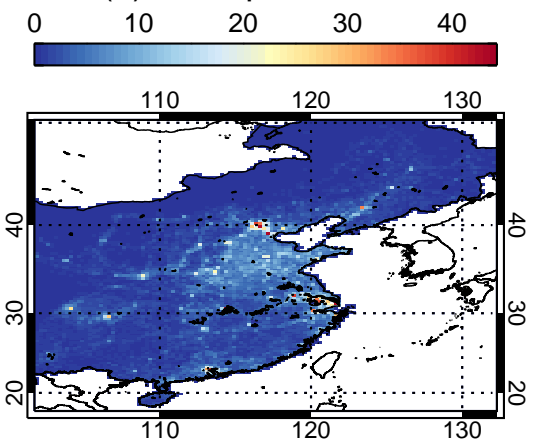

Figure 1. The $\mathrm{SO}_{2}$ MEIC v1.2 emissions in megagrams per month for March 2010. The relative strength of the four sectors is shown here: industry (a), power (b), residential (c) and transportation (d). Note the different colour bars used.

\subsection{The MEIC emission inventory}

The Multi-resolution Emission Inventory for China (MEIC v1.2) model has been developed for the years 2008, 2010 and 2012 by the School of Environment, Tsinghua University, Beijing, China, and is downloadable from http://www. meicmodel.org/ (last access: 20 March 2018). $\mathrm{SO}_{2}$ emissions, in megagrams per month, are calculated on a monthly basis for four sectors - power, industry, residential and transportation - at a spatial resolution of $0.25^{\circ} \times 0.25^{\circ}$. The domain applicable spans from $15^{\circ}$ to $55^{\circ} \mathrm{N}$ and from $102^{\circ}$ to $132^{\circ} \mathrm{E}$. For the requirements of the methodology applied here the error in these emissions has been assumed to rise to $50 \%$ of the actual reported value since the MEIC inventory does not include such an error estimate, nor were we able to procure such a value from the literature.

An example of the $\mathrm{SO}_{2}$ MEIC v1.2 emissions in megagrams per month for March 2010 is shown in Fig. 1. The relative strength of the four sectors is shown as well, with industry in the top left panel, the power sector in the top right, the residential emissions in the bottom left and transportation in the bottom right. Different colour scales in the panels were used for the different emission strengths. In Zhang et al. (2015) the 2010 MEIC v1.2 emissions were used as spin-up information in order to perform sensitivity simulations with different $\mathrm{SO}_{2}$ emission reduction scenarios. It was shown that reducing $\mathrm{SO}_{2}$ emissions from one region has a small effect on $\mathrm{SO}_{2}$ concentrations over the other regions. The national mean $\mathrm{SO}_{2}$ concentration however is most sensitive to $\mathrm{SO}_{2}$ emissions from northern China, in this work called the greater Beijing area. This strengthens the importance of providing accurate and updated emission levels over that region in China even though it is considered to be the best represented within existing inventories since the large population and industry density render the evaluation of emission levels easier than in remote, less populated, regions.

\subsection{The $\mathrm{OMI} /$ Aura $\mathrm{SO}_{2}$ observations}

The Ozone Monitoring Instrument (OMI) is a nadir-viewing instrument on board the NASA Aura satellite flying in a Sun-synchronous polar orbit with an Equator-crossing time of around 13:30 LT in the ascending node launched in July 2004. The OMI imaging spectrograph measures backscattered sunlight in the ultraviolet-visible range from 270 to $500 \mathrm{~nm}$ with a spectral resolution of about $0.5 \mathrm{~nm}$ (Levelt et al., 2006). The OMI spatial swath is around $2600 \mathrm{~km}$ wide, achieving near-complete global coverage in approximately 1 day. The OMI ground pixel size varies from 
$13 \mathrm{~km} \times 24 \mathrm{~km}$ at nadir to $28 \mathrm{~km} \times 150 \mathrm{~km}$ at the edges of the swath. Since June 2007, the radiance data of OMI for some particular viewing directions have been corrupt, a feature known as the OMI row anomaly (http://projects.knmi.nl/ omi/research/product/rowanomaly-background.php, last access: 20 March 2018). Hence, the suggested OMI observations are excluded de facto from the analysis.

In this work, we employ the retrieved $\mathrm{SO}_{2}$ vertical column densities (VCDs) using the BIRA algorithm (Theys et al., 2015) which are calculated using the differential optical absorption spectroscopy (DOAS) technique (Platt and Stutz, 2008) to the measured spectra in the $312-326 \mathrm{~nm}$ wavelength range. This step is followed by data filtering for the row anomaly issue and a background correction to account for possible biases in the retrieved slant columns. The obtained quantity is converted into a $\mathrm{SO}_{2} \mathrm{VCD}$ using an air mass factor, AMF, which accounts for changes in measurement sensitivity due to observation geometry, ozone column, clouds and surface reflectivity. The anthropogenic $\mathrm{SO}_{2}$ profile required in the AMF calculation has been extracted from the Intermediate Model of the Global and Annual Evolution of Species, IMAGESv2, global tropospheric chemistry transport model (Stavrakou et al., 2013, and references therein) on a daily basis and for the overpass time of OMI. All details on the BIRA $\mathrm{OMI} \mathrm{SO}_{2}$ algorithm can be found in Theys et al. (2015), updated recently in Theys et al. (2017) in preparation for TROPOspheric Monitoring Instrument (TROPOMI) instrument. The dataset has already been employed in different studies: in van der A et al. (2017) in order to estimate the effectiveness of current air quality policies for $\mathrm{SO}_{2}$ and $\mathrm{NO}_{x}$ emissions in China; in Koukouli et al. (2016) in order to quantify the anthropogenic $\mathrm{SO}_{2}$ load over China using different satellite instruments and algorithms; and in Schmidt et al. (2015) in order to study the 2014-2015 Bárðarbunga-Veiðivötn fissure eruption in Iceland, among others.

The domain considered extends from $18^{\circ}$ to $50^{\circ} \mathrm{N}$ and from $102^{\circ}$ to $132^{\circ} \mathrm{E}$ and covers eastern China. Daily observations were filtered for high solar zenith angle (SZA) of $>70^{\circ}$, cloud fraction $>0.2$ and row anomaly flagging as per Theys et al. (2017). The filtered data were then averaged onto a $0.25^{\circ} \times 0.25^{\circ}$ monthly grid using a $0.75^{\circ}$ smoothing average box. For further details on this pre-processing, refer to Koukouli et al. (2016).

Within the OMI BIRA $\mathrm{SO}_{2}$ product, error contributions resulting from each step of the retrieval to the final vertical column error are provided separately, including their random and systematic parts (Theys et al., 2017). This allows the estimation of the total error in the column averages, an important feature in this analysis where the instantaneous OMI observations are gridded and then averaged on a monthly mean basis. The formulation of the error in the vertical $\mathrm{SO}_{2}$ column is derived by basic error propagation, shown in Eq. (1):

$\sigma_{N_{\mathrm{V}}}^{2}=\left(\frac{\sigma_{N_{\mathrm{s}}}}{M}\right)^{2}+\left(\frac{\sigma_{N_{\mathrm{s}}^{\text {back }}}}{M}\right)^{2}+\left(\frac{\left(N_{\mathrm{s}}-N_{\mathrm{s}}^{\text {back }}\right) \sigma_{M}}{M^{2}}\right)^{2}$, where $\sigma_{N_{\mathrm{s}}}, \sigma_{M}$ and $\sigma_{N_{\mathrm{s}}^{\text {back }}}$ are the errors in the slant column $\left(N_{\mathrm{S}}\right)$, the air mass factor $(M)$ and the reference correction $\left(N_{\mathrm{s}}^{\text {back }}\right)$, respectively. When averaging the observations, the systematic and random components of each given error source need to be discriminated, and so Eq. (1) evolves into Eq. (2):

$$
\begin{aligned}
\sigma_{N_{\mathrm{V}}}^{2}= & \frac{1}{M^{2}}\left(\sigma_{N_{\mathrm{S}_{-} \mathrm{syst}}}^{2}+\frac{\sigma_{N_{\mathrm{S} \_ \text {rand }}}^{2}}{N}+\frac{\Delta N_{\mathrm{s}}^{2}}{M^{2}} \sigma_{M_{-} \mathrm{syst}}^{2}\right. \\
& \left.+\frac{\Delta N_{\mathrm{s}}^{2}}{M^{2}} \frac{\sigma_{M_{-} \text {rand }}^{2}}{N}\right),
\end{aligned}
$$

where $N$ is the number of ground pixels considered in the average and $\sigma_{N_{\text {s_s syst }}}$ is the systematic uncertainty in the slant column density, SCD, which also includes the systematic uncertainty associated with the background correction. The VCD is denoted by $N_{\mathrm{V}}$, the SCD by $N_{\mathrm{s}}$, the SCD minus the SCD_correction by $\Delta N_{\mathrm{s}}$, the AMF by $M$, the VCD precision by $\sigma_{N_{\mathrm{V}}}$, the SCD precision by $\sigma_{N_{\mathrm{S} \_} \text {rand }}$, the AMF precision by $\sigma_{M_{-} \text {rand }}$ and the AMF trueness by $\sigma_{M_{-} \text {syst }}$. The error analysis is accompanied by the total column averaging kernel (AK) calculated as the weighting function divided by the air mass factor, $M$ (Eskes and Boersma, 2003). The weighting function characterizes the sensitivity of the extracted atmospheric column to changes in the true profile, and its importance in the analysis of satellite observations, alongside their correct comparison to other datasets, has long been established (see for example Rodgers, 2000; Ceccherini and Ridofli, 2010; Zhang et al., 2010). In Sect. 2.3 the importance of the AKs in co-analysing satellite observations and modelling results in this work is discussed extensively.

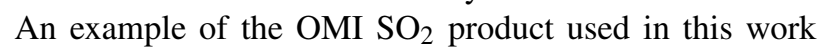
is shown in Fig. 2, for the month of March 2010. The retrieved $\mathrm{SO}_{2} \mathrm{VCD}$ in Dobson units (D.U.) is shown in the upper panel, with the systematic component to the error in the bottom left and the random component in the bottom right.

In the original work of Martin et al. (2006), which was based on GOME/ERS-2 observations and GEOS-CHEM model data at a resolution of $2^{\circ}$ by $2.5^{\circ}$, the authors conclude that the major limitations in their work were the coarse horizontal resolution of GOME - which is not the case here for OMI - and the lack of direct validation of the GOME tropospheric $\mathrm{NO}_{2}$ product - again, not the case here as the OMI BIRA $\mathrm{SO}_{2}$ measurements have already been verified against other satellite observations (Bauduin et al., 2016; Koukouli et al., 2016) as well as long-term ground-based measurements in polluted locations (Theys et al., 2015; Wang et al., 2017). However, we would be amiss not to mention the issue of the possible horizontal transport of $\mathrm{SO}_{2}$ during its lifetime in the lower troposphere, which would alter the linear relationship inherent in Eq. (3). Hains et al. (2008) calculated the $\mathrm{SO}_{2}$ lifetime on a global scale to be $19 \pm 7 \mathrm{~h}$, whereas Lee et al. (2011) have updated this estimate, at northern US mid-latitudes where anthropogenic emissions dominate, to 

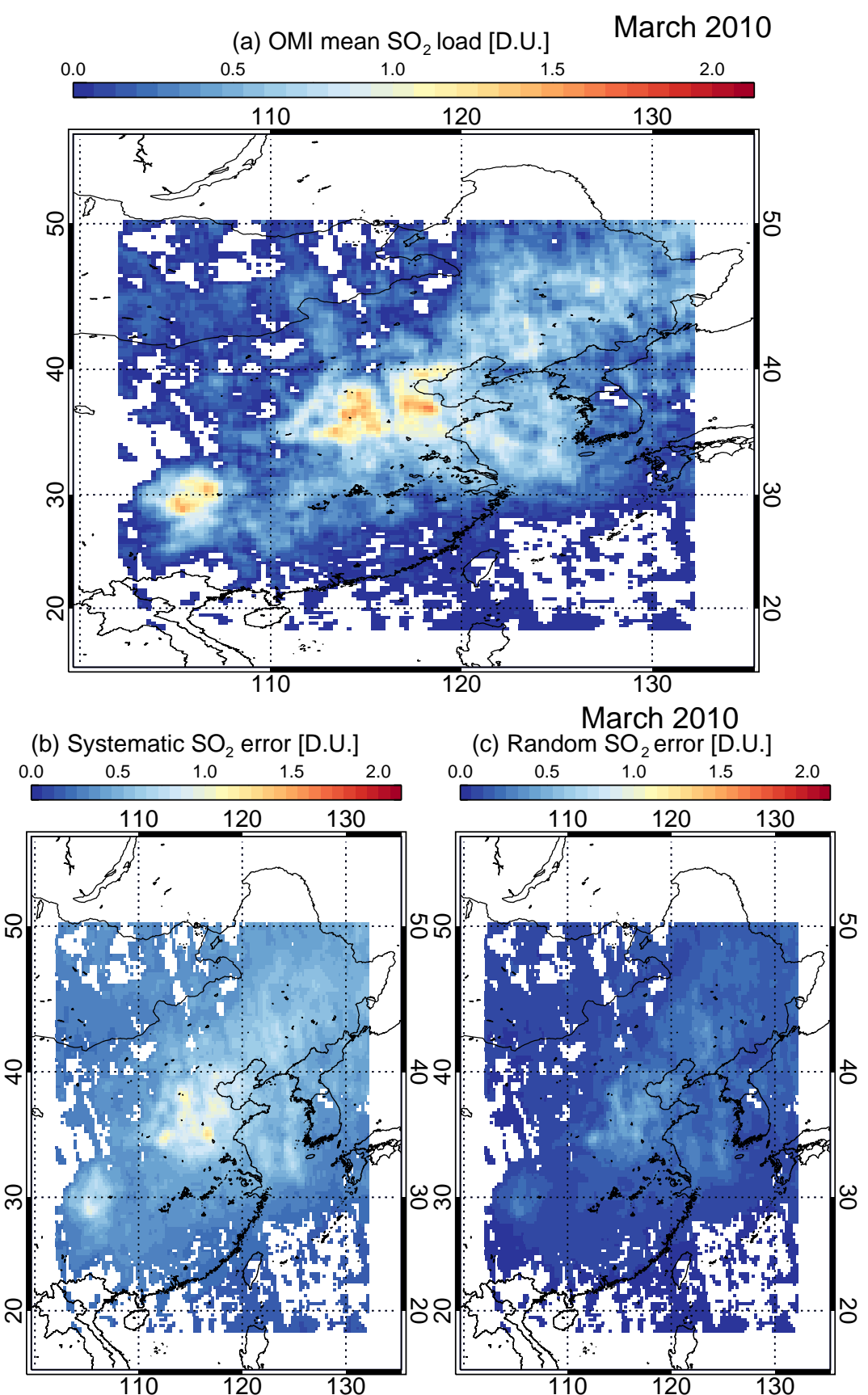

Figure 2. (a) The monthly mean OMI/BIRA $\mathrm{SO}_{2}$ columns in D.U. for March 2010. (b) The associated systematic error (left) and random error (right) in D.U. calculated using Eq. (2).

$16-40 \mathrm{~h}$ with a maximum in winter and a minimum in summer. Using OMI/Aura observations over the highest-emitting power plant locations in the US, Fioletov et al. (2015), have provided shorter lifetime estimates of between 4 and $12 \mathrm{~h}$. Even though it is hence not inconceivable that with moderate wind speeds $\mathrm{SO}_{2}$ may have traversed a grid point on our $0.25^{\circ} \times 0.25^{\circ}$ grid, on the monthly mean scale that this work is based on it is impossible to evaluate the magnitude to this possible smearing effect.

\subsection{The CHIMERE model output}

A multi-scale model for air quality forecasting and simulation, CHIMERE (http://www.lmd.polytechnique.fr/ chimere/; last access: 20 March 2018), provides $\mathrm{SO}_{2}$ profiles over the Chinese domain of $18-50^{\circ} \mathrm{N}, 102-132^{\circ} \mathrm{E}$ for 
the mean overpass hour of OMI/Aura over the domain. The model version is CHIMERE v2013b (Menut et al., 2013) at a spatial resolution of $0.25^{\circ} \times 0.25^{\circ}$ and on eight vertical levels in ppb, i.e. seven vertical layers, spanning from the surface up to $500 \mathrm{hPa}$, for the year 2010. The meteorological input was provided by ECMWF (http://www.ecmwf. int/; last access: 20 March 2018) operational data. The anthropogenic emission inventory in this CHIMERE run was a mix of the MEIC v1.2 inventory for mainland China and the Intercontinental Chemical Transport Experiment - Phase B (INTEX-B) emission inventory, https://cgrer.uiowa.edu/ projects/emmison-data (last access: 20 March 2018) for areas outside China. The biogenic emissions are provided by the MEGAN database (http://lar.wsu.edu/megan/; last access: 20 March 2018). For the background of the particular CHIMERE set-up refer to Mijling and van der A (2012), whereas more specific details on the CHIMERE v2013b run used here may be found in Ding et al. (2015).

The uncertainty of the CHIMERE $\mathrm{SO}_{2}$ columns is assumed to rise to $25 \%$. Estimating mathematically modelling errors is quite challenging due to the large number of modelling processes and input parameters that have no defined error, such as the boundary and initial conditions, the species emissions, rate constant uncertainties, and even unresolved aspects of atmospheric physics and chemistry (Deguillaume et al., 2008; Boersma et al., 2016). Typically such uncertainties are deduced from comparisons to other CTMs (Pirovano et al., 2012) and/or to independent observational datasets (Lee et al., 2009). Even so, due to the innumerous differences in mathematically expressing atmospheric processes in the former case and between model simulations and observations in the latter case, calculating a definite value remains elusive. In Fig. 3, the March 2010 CHIMERE integrated $\mathrm{SO}_{2}$ column is shown as an example for the domain in question.

Before proceeding to the convolution of the CHIMERE profiles to the OMI AKs and subsequent vertical integration, we investigated whether the differences in orography heights assumed by the CHIMERE and OMI datasets in the respective algorithms may introduce artefacts into the final CHIMERE VDCs. Zhou et al. (2009) have shown that, for the case of $\mathrm{NO}_{2}$ profiles retrieved from OMI measurements over the Po Valley and the Alps, the difference in orography between satellite pixel and chemistry transport modelling (CTM) grid may lead to either over- or underestimation of the $\mathrm{NO}_{2}$ VCDs by between 10 and $25 \%$. Theys et al. (2017), in order to utilize more realistic a priori $\mathrm{SO}_{2}$ profiles, employed CTM model profiles at $1^{\circ} \times 1^{\circ}$ resolution and used the hypsometric equation (Eq. 3) to scale them down to the future TROPOMI/S5P $7 \mathrm{~km} \times 3.5 \mathrm{~km}$ spatial resolution. In this equation, a new effective pressure, $P_{\text {eff }}-$ which differs from the model surface pressure, $P_{\text {ERA }}-$ is calculated under the assumption that the surface temperature, $T_{\text {ERA }}$, varies linearly with height with a lapse rate of $\Gamma=-6.5 \mathrm{~K} \mathrm{~km}^{-1}$, gas constant of $R=287 \mathrm{~J} \mathrm{~kg}^{-1} \mathrm{~K}^{-1}$ and gravitational acceleration of $g=9.8 \mathrm{~m} \mathrm{~s}^{-2}$. This variation depends on the dif-
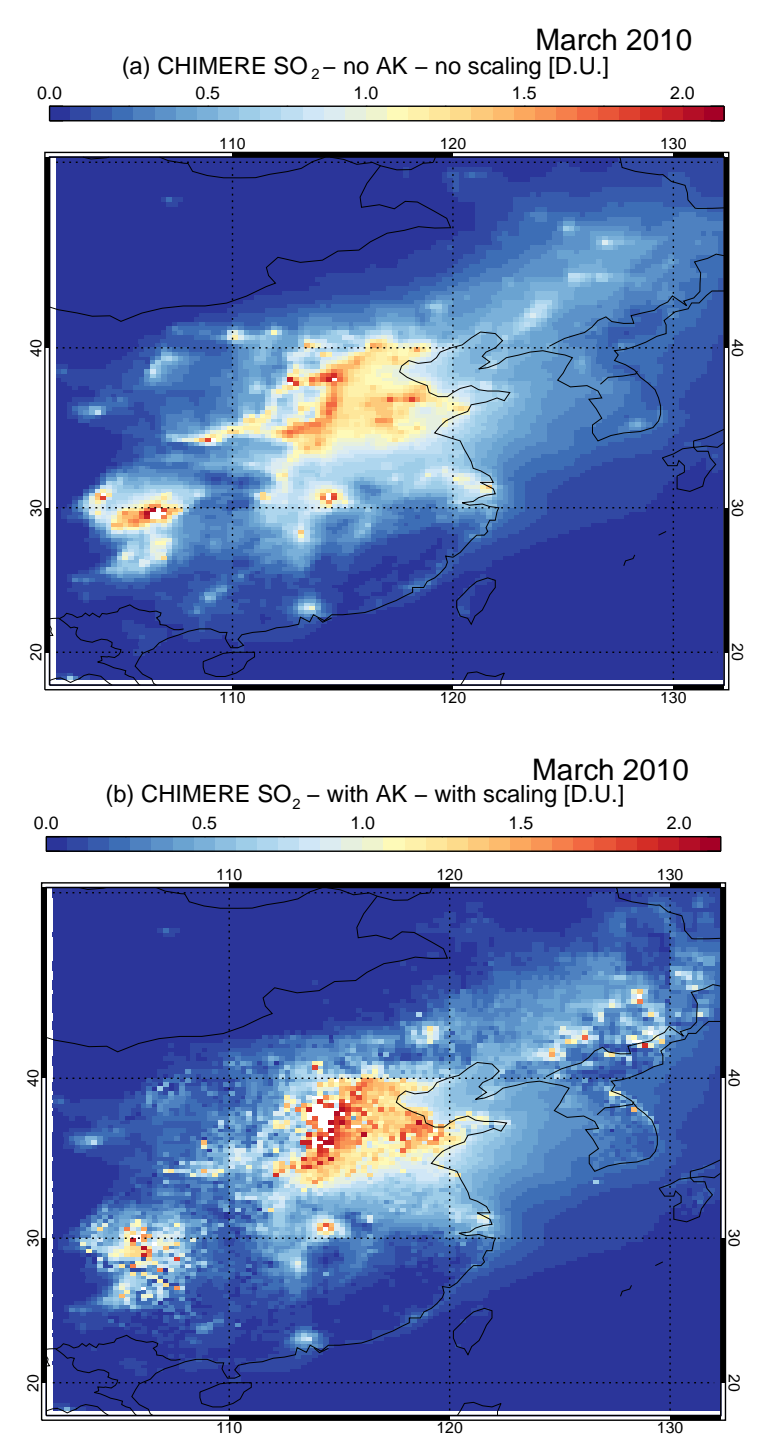

Figure 3. The March $2010 \mathrm{SO}_{2}$ columns in D.U. as integrated in height from the original CHIMERE model ppb levels: (a) without rescaling to the effective pressure and without convolution with the OMI AKs; (b) with rescaling and with convolution with the OMI AKs.

ference between the orography height of CHIMERE, $h_{\mathrm{CHIM}}$, and the OMI-reported height per observation, $h_{\text {eff }}$. The surface pressure and temperature have been extracted from the ERA-Interim dataset (https://www.ecmwf.int/en/research/ climate-reanalysis/era-interim; last access: 20 March 2018) at a daily temporal and $0.75^{\circ} \times 0.75^{\circ}$ spatial resolution (Dee et al., 2011).

In the case of $\mathrm{SO}_{2}$ anthropogenic emissions, this whole issue may be significant in locations where the surface height changes significantly within our $0.25^{\circ} \times 0.25^{\circ}$ grid, whereupon the OMI pixel may have viewed an entirely different atmospheric state, by more than $\sim 1 \mathrm{~km}$ in the vertical. In this work and for the entire 10 years of OMI observations, 

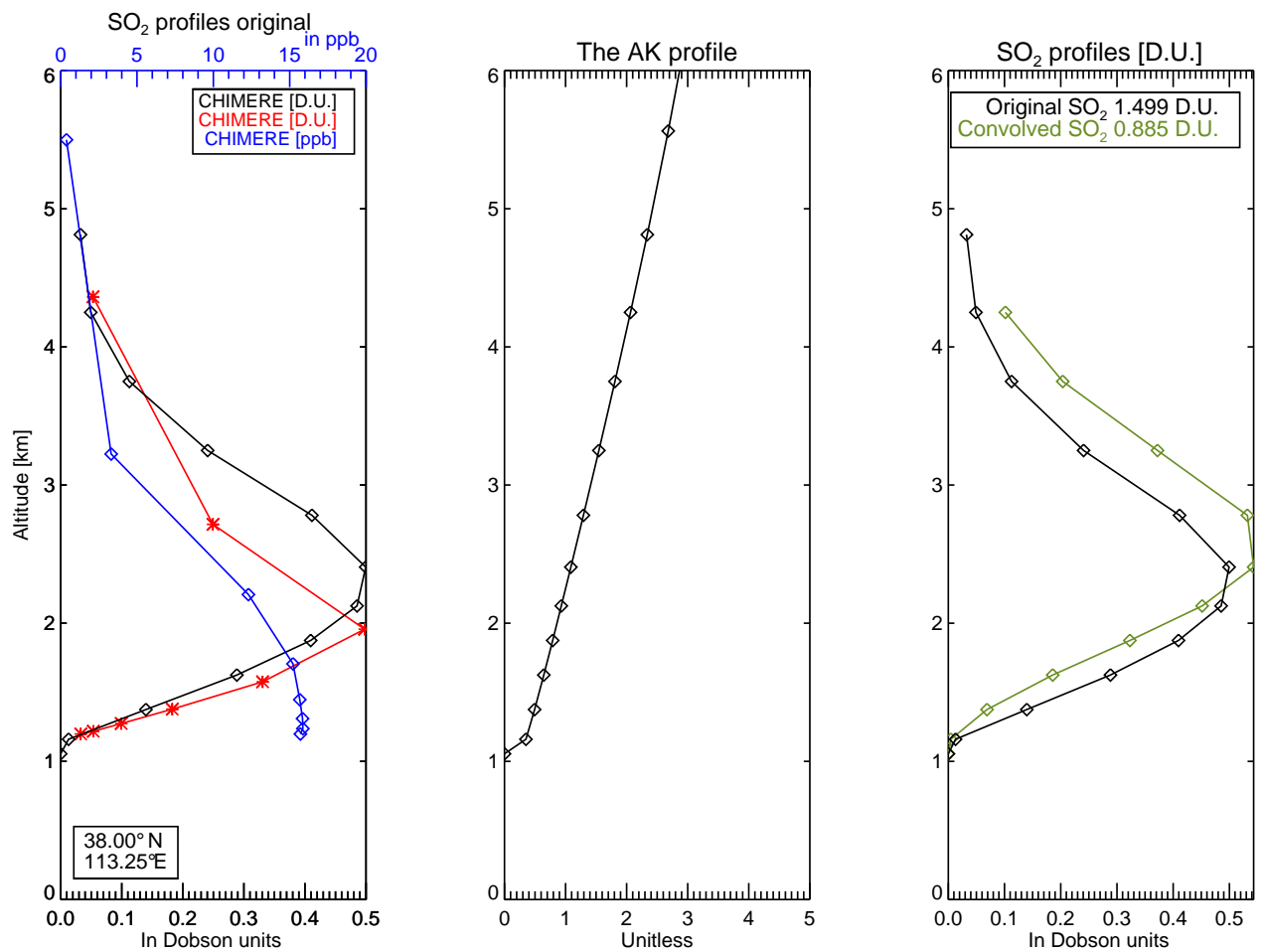

Figure 4. An example of the convolution of the CHIMERE $\mathrm{SO}_{2}$ profile with the OMI averaging kernel to produce the convolved CHIMERE total $\mathrm{SO}_{2}$ column for the grid of $38.0^{\circ} \mathrm{N}, 113.25^{\circ} \mathrm{E}$. (a) The original CHIMERE $\mathrm{SO}_{2}$ profile of eight levels in ppb is shown in blue; the same profile but in Dobson units per layer is given in red, whereas the profile in D.U. but of 58 OMI AK levels is given in black. (b) The OMI AK profile. (c) The original CHIMERE profile in D.U. per layer is shown in black, as in (a), and the convolved CHIMERE profile in D.U. per layer is shown in olive green. The original CHIMERE total $\mathrm{SO}_{2}$ column is 1.50 D.U., whereas after convolution with the OMI AK it decreases to 0.885 D.U.

only $3 \%$ of the entire domain of 15609 grid points show an overestimation of $h_{\mathrm{CHIM}}$ heights above $500 \mathrm{~m}$ and fewer than $0.5 \%$ of the grid points show an overestimation of $h_{\mathrm{eff}}$ heights.

$P_{\mathrm{eff}}=P_{\mathrm{ERA}}\left(\frac{T_{\mathrm{ERA}}}{T_{\mathrm{ERA}}+\Gamma\left(h_{\mathrm{CHIM}}-h_{\mathrm{eff}}\right)}\right)^{-g / R \Gamma}$

Even so, and for the sake of completeness, the CHIMERE profiles were re-scaled accordingly to the new pressure levels, calculated from $P_{\text {eff }}$ and the CHIMERE pressure parameters as applied in Eqs. (2) and (6) of Zhou et al. (2009). Grid points with associated CHIMERE heights of greater than $1500 \mathrm{~m}$, which represent $7.5 \%$ of the domain, almost exclusively in the westernmost part (west of $110^{\circ} \mathrm{E}$ ) where the Tibetan Plateau rises, are excluded from this re-scaling due to interpolation issues. Those pixels are in any case excluded in the analysis for the new emission database further on due to their non-existent $\mathrm{SO}_{2}$ contributions. Overall, the non-seasonally dependent differences found in the CHIMERE columns before and after scaling were of the order of $\sim 10-12 \%$, on the low side of the estimates for $\mathrm{NO}_{x}$ by Zhou et al. (2009), who were however faced with far greater topological variabilities in the locations of their study.
As a consequence, we consider the convolution of modelling profiles to the satellite AK a far more important factor in the solidity of the proposed methodology than anything else.

An extremely small fraction of our domain showed significant variation of above 0.5 D.U. in absolute differences, of fewer than $\sim 0.05 \%$ of the pixels for the entire domain irrespective of month, due to numerical uncertainties introduced by the re-shaping, re-scaling and altering between the different altitude domains of the CHIMERE and OMI profiles. Hence, for the main aim of this paper, which is to update the $\mathrm{SO}_{2}$ emission spatial inventory over eastern China and not to provide absolute $\mathrm{SO}_{2}$ emitted quantities, we deem this difference well within the final emission inventory error budget discussed below in Sect. 4.1.

We then proceed in convolving the re-scaled CHIMERE profiles with the OMI column averaging kernel as discussed in Eskes and Boersma (2003) and Boersma et al. (2008a). The CHIMERE model profiles were already in a $0.25^{\circ} \times 0.25^{\circ}$ monthly grid, whereas the OMI observations are daily measurements in a variable pixel size, from $13 \times 24 \mathrm{~km}^{2}$ at nadir to $28 \times 150 \mathrm{~km}^{2}$ at the edges of the swath. Hence, the CHIMERE profile for each grid was convolved with each of the corresponding OMI AKs that 
fall within the same $0.25^{\circ} \times 0.25^{\circ}$ grid and then averaged (see Fig. 3, bottom). On average, the convolution of the CHIMERE re-shaped profiles with the OMI AKs introduced a seasonally dependent decrease in the $\mathrm{SO}_{2}$ modelled levels, between $\sim 0-5 \%$ (for the summer months) and 10-15\% (for the autumn-winter months) for the entire domain, as expected.

An example of this entire process is provided in Fig. 4 for the grid box $38.0^{\circ} \mathrm{N}, 113.25^{\circ} \mathrm{E}$, a location slightly to the west of the greater Beijing area with a moderate orography height of $\sim 1 \mathrm{~km}$. In the left panel the original CHIMERE $\mathrm{SO}_{2}$ profile of eight levels in ppb is shown in blue; the same profile but in Dobson units per layer is given in red, whereas the profile in Dobson units but for the OMI AK levels is given in black since the OMI algorithm performs calculations on a 58-level pressure grid. The $y$ axis ranges up to $\sim 5 \mathrm{~km}$, which is approximately the vertical range of the CHIMERE model. In the middle panel the OMI AK profile is presented. In the right panel the original CHIMERE profile in Dobson units is shown again in black so as to compare easily to the convolved CHIMERE profile, in olive green. In the insert of this panel, the total $\mathrm{SO}_{2}$ load in D.U. for the two profiles is also given. The re-shaped CHIMERE total $\mathrm{SO}_{2}$ column is 1.50 D.U., whereas after convolution with the OMI AK it decreases to 0.885 D.U., while the actual load is also restructured in order to approach the atmosphere sense by the satellite instrument. It is hence shown that even though the total column has not changed the vertical distribution of that column does change to reflect the sensitivity of the satellite observations, which peaks higher up in the boundary layer and lower troposphere.

\section{Mathematical nomenclature}

\subsection{Top-down and a posteriori emissions estimates}

The inversion methodology applied here is the one first presented in Martin et al. (2003) and further applied in Martin et al. (2006), Boersma et al. (2008b), Lamsal et al. (2010), Lin et al. (2010), Gu et al. (2014) and Zyrichidou et al. (2015), among others. The main premise of the methodology resides in the mass balance equation (Leue et al., 2001) and requires three input parameters: the a priori emission field, $E_{\mathrm{a}}$ (Sect. 2.1); the satellite-derived $\mathrm{SO}_{2}$ field, $\Omega_{\mathrm{t}}$ (Sect. 2.2); and the model $\mathrm{SO}_{2}$ field, $\Omega_{\mathrm{a}}$ (Sect. 2.3). Using those, as per Eq. (4), the top-down emission inventory, $E_{\mathrm{t}}$, is calculated. Using standard propagation error analysis, the error in the top-down emission field may be calculated through Eq. (5), where the error in the a priori emissions, $\varepsilon_{\mathrm{a}}$, is required, as well as the error on the model estimates, $\varepsilon_{\Omega a}$, and the satellite retrieval error, $\varepsilon_{\Omega t}$. These error levels have been discussed in the equivalent sections.

$$
\begin{aligned}
& E_{\mathrm{t}}=E_{\mathrm{a}} \cdot \frac{\Omega_{\mathrm{t}}}{\Omega_{\mathrm{a}}} \\
& \varepsilon_{\mathrm{t}}^{2}=\left(\frac{\Omega_{\mathrm{t}}}{\Omega_{\mathrm{a}}} \cdot \varepsilon_{\mathrm{a}}\right)^{2}+\left(\frac{E_{\mathrm{a}}}{\Omega_{\mathrm{a}}} \cdot \varepsilon_{\Omega t}\right)^{2}+\left(\frac{E_{\mathrm{a}} \Omega_{\mathrm{t}}}{\Omega_{\mathrm{a}}^{2}} \cdot \varepsilon_{\Omega_{\mathrm{a}}}\right)^{2}
\end{aligned}
$$

The calculated top-down emission inventory, $E_{\mathrm{t}}$, may be combined with the a priori emission inventory, $E_{\mathrm{a}}$, to provide an a posteriori emission inventory, $E_{\mathrm{p}}$, following the maximum-likelihood theory and a log-normal distribution of errors. In Eq. (6) the calculation of the a posteriori emission inventory is given, and its associated relative error is given in Eq. (7). Hence, in this methodology, the original bottom-up emission inventory is combined with the top-down satellite observations, weighted by their respective errors and using modelling outputs as background field, in order to constrain, update and provide new emissions estimates. It also follows that since the a priori emission field is weighted by the topdown emission field error, and vice versa, the a posteriori will depend mostly on the a priori should the errors of the top-down be too large, and vice versa. In that way, it is assured that, at locations where the satellite observations are too sparse or the information content in the $\mathrm{SO}_{2}$ load too low, the a posteriori emission field will revert back to the a priori.

$$
\begin{aligned}
& \ln E_{\mathrm{p}}=\frac{\ln E_{\mathrm{a}}\left(\ln \varepsilon_{\mathrm{t}}\right)^{2}+\ln E_{\mathrm{t}}\left(\ln \varepsilon_{\alpha}\right)^{2}}{\left(\ln \varepsilon_{\mathrm{t}}\right)^{2}+\left(\ln \varepsilon_{\mathrm{a}}\right)^{2}} \\
& \left(\ln \varepsilon_{\mathrm{p}}\right)^{-2}=\left(\ln \varepsilon_{\mathrm{t}}\right)^{-2}+\left(\ln \varepsilon_{\mathrm{a}}\right)^{-2}
\end{aligned}
$$

We should clarify at this point that the calculations of Eq. (4) to Eq. (6) are performed for domain space; i.e. for the sake of completeness these equations should have an $i, j$ indicator everywhere designating the lat.-long. location of the gridded domain space. The $i, j$ were not included because it was deemed the equations would become too complicated unnecessarily. However, the relative error calculated by Eq. (7), which represents the geometric SD about the expected value as per Martin et al. (2003), is calculated on the final, total top-down error, $\varepsilon_{\mathrm{t}}$, and a priori error, $\varepsilon_{\mathrm{a}}$, which are calculated as the known summation of error terms,

$\varepsilon^{2}=\varepsilon_{i, j}^{2}+\varepsilon_{i, j+1}^{2}+\ldots+\varepsilon_{i+1, j}^{2}+\varepsilon_{i+1, j+1}^{2}+\ldots$.

In the very recent paper by Cooper et al. (2017) an iterative version of the mass balance methodology (Martin et al., 2003) was shown to provide results of similar accuracy to the more computationally demanding adjoint method (used for e.g. in Stavrakou et al., 2013) in estimating satellite-born $\mathrm{NO}_{x}$ emissions, which encourages the usage of the mass balance technique when one cannot employ modelling results that calculate an adjoint matrix as well.

\subsection{Roadmap of this analysis}

The statistical methodology described above will be applied to the entire 11 years of OMI/Aura observations, from 2005 


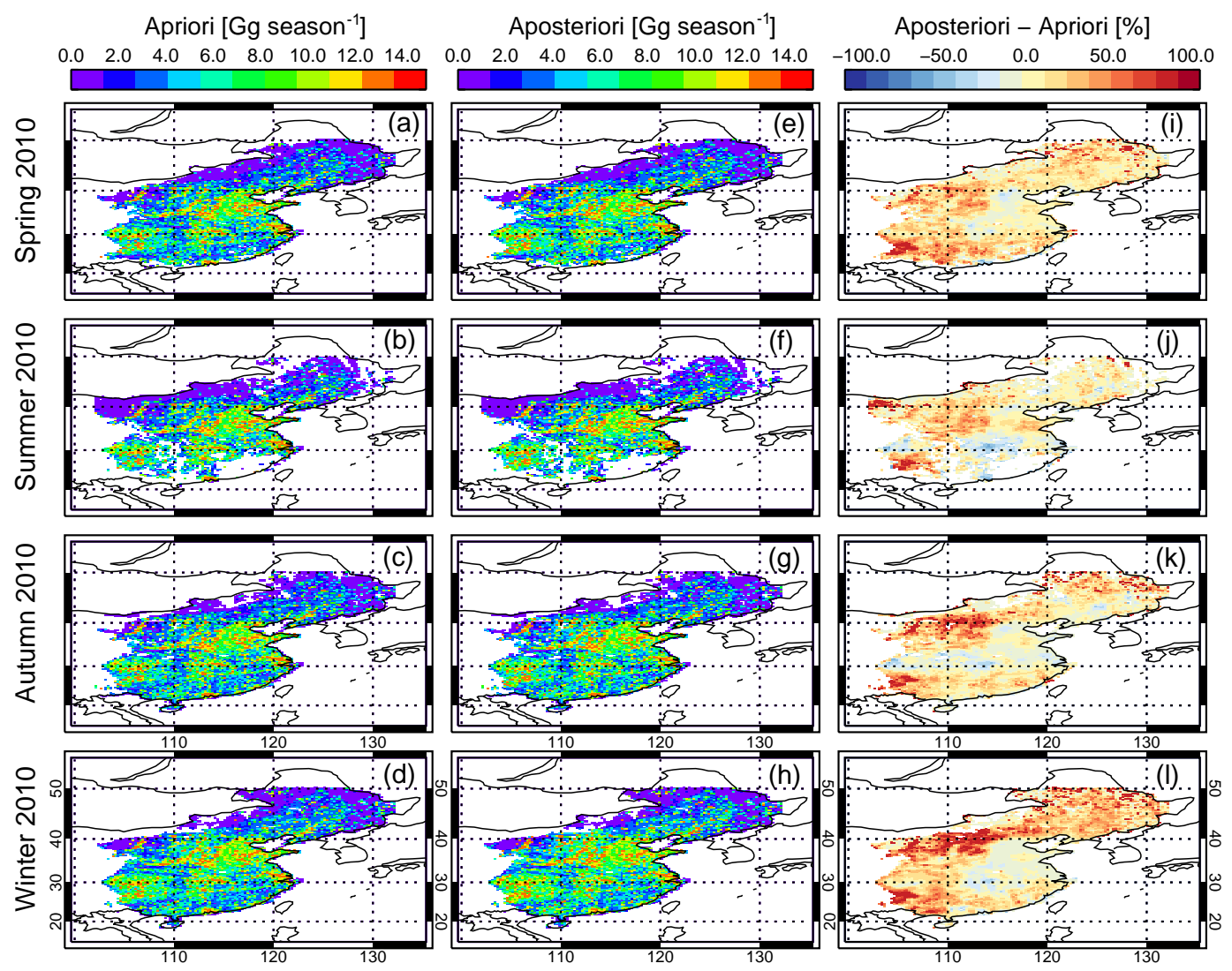

Figure 5. The seasonal variability of the a posteriori emissions calculated in this work (e-h) in gigagrams per season compared to the a priori MEIC v1.2 emissions (a-d) in Gg season ${ }^{-1}$ as well as their percentage differences (i-l) in percent. From top to bottom; spring, summer, autumn and winter of reference year 2010.

to 2015. Since the CHIMERE v2013b simulations were performed using the 2010 MEIC v1.2 inventory, the year 2010 will be used as a reference year in the following analysis. The first step is to present the 2010 updated emissions over the entire domain and how these compare against the a priori emissions; secondly, monthly mean time series of different locations within the domain are shown, and the changes of the $\mathrm{SO}_{2}$ emissions over the years are discussed. Finally, comparisons against pre-existing bottom-up emission inventories are presented.

\section{Results and statistics}

\subsection{Updated emissions over China}

In Fig. 5 the seasonal variability of the a posteriori emissions calculated with the methodology above is shown in the middle column for spring, summer, autumn and winter (top to bottom). The equivalent MEIC v1.2 a priori inventory on the same seasonal basis is shown in the left column, and the percentage differences of the two in the right column. The main take-away message from this pictorial representation of the inventory is that the new inventory is producing higher emissions for the entire domain for all seasons, which are stronger in winter and have positive biases that span from $\sim 10 \%$ to $\sim 35 \%$ accordingly (Table 1 ). Note from the fifth column of the Table the amount of grid points that actually provide information out of an original 8414 grid cells for the domain considered in this work, i.e. the grid cells of the MEIC v1.2 inventory. In the final column of the table, the percentage differences between the two inventories are calculated in two ways: the first value depicts the difference between the first and third columns, i.e. on the sum of emissions for the entire domain. The second value, in square brackets, has been calculated as the mean of the per-grid-point percentage differences within the domain; hence it contains the geographical deviations of the emission inventories as well. In order to further delve into this geographical variability, we present in Fig. 6 time series of emissions over four domains of interest: the entire domain studied $\left(18-50^{\circ} \mathrm{N}, 102-132^{\circ} \mathrm{E}\right)$, the greater Beijing region $\left(30-40^{\circ} \mathrm{N}, 110-120^{\circ} \mathrm{E}\right)$, the southwest region $\left(25-35^{\circ} \mathrm{N}, 100-110^{\circ} \mathrm{E}\right)$ and the northeast region $\left(40-50^{\circ} \mathrm{N}, 120-130^{\circ} \mathrm{E}\right)$. The two regions in the corners of the area studied were chosen since high $\mathrm{SO}_{2}$ levels were observed by OMI, resulting in increased emissions in the a pos- 

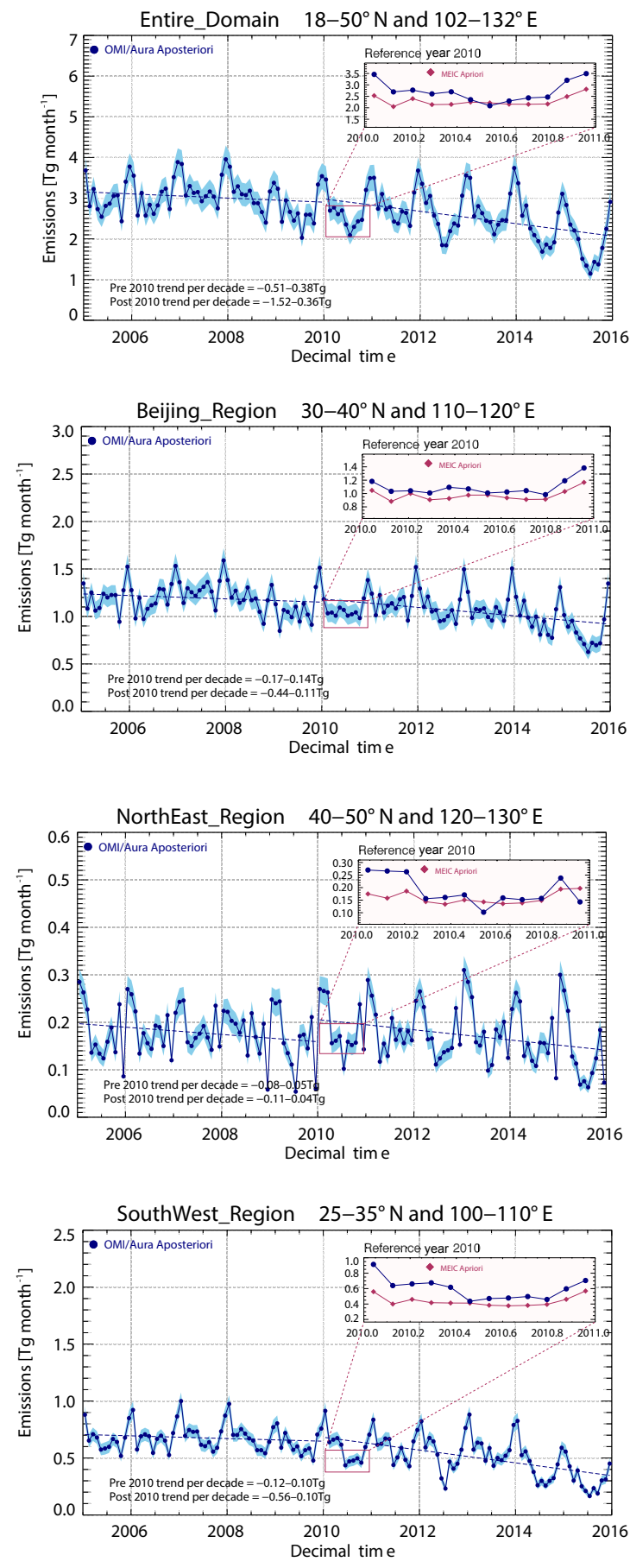

Figure 6. Monthly mean time series for the a posteriori emissions in teragrams per month calculated in this work (dark blue points) between 2005 and 2015. Insert: the reference year 2010 is shown to include the MEIC v1.2 a priori emissions in maroon diamonds. The light blue shaded area depicts the calculated a priori error (Eq. 7). (a) The entire domain studied $\left(18-50^{\circ} \mathrm{N}, 102-132^{\circ} \mathrm{E}\right)$, (b) the greater Beijing region $\left(30-40^{\circ} \mathrm{N}, 110-120^{\circ} \mathrm{E}\right)$, (c) the northeast region $\left(40-50^{\circ} \mathrm{N}, 120-130^{\circ} \mathrm{E}\right)$ and (d) the southwest region (25$\left.35^{\circ} \mathrm{N}, 100-110^{\circ} \mathrm{E}\right)$. teriori inventory, which do not appear in the original MEIC v1.2 dataset.

In Fig. 6 the monthly mean time series for the a posteriori emissions in teragrams per month (dark blue lines) are presented for the four domains of interest, so as to enable a more in-depth discussion of the new inventory. The light blue shaded area depicts the extracted a posteriori error in the emissions, and the inset sub-figures depict the reference year 2010, with the a posteriori levels shown in blue and the MEIC $\mathrm{v} 1.2$ emissions in maroon. The pre- and post-2010 drifts are also calculated since the year 2010 is considered a turning point as far as regulating $\mathrm{SO}_{2}$ emissions is concerned (Wang et al., 2015; van der A et al., 2017, and references therein). A very similar picture was shown for all domains: a nearstable decrease in emissions within the statistical error of the analysis for the pre-2010 levels and a stronger and statistically significant decrease for the post-2010 levels.

For the entire domain (Fig. 6a) a posteriori emissions in all months show an increase for the year 2010 compared to the a priori MEIC inventory, apart from the summer (JJA) ones, with the highest increases for the winter months. The pre-2010 drift is calculated at the limit of statistical significance, at $-0.51 \pm 0.38 \mathrm{Tg} \mathrm{month}^{-1}$, whereas the post-2010 drift is stronger and significant at $-1.52 \pm 0.36 \mathrm{Tg}^{\text {month }}{ }^{-1}$. For the greater Beijing region (Fig. 6b) a small increase in emissions, nearly constant in all months of 2010, is found with the post-2010 drift to also be negative at the $-0.44 \pm 0.11 \mathrm{Tg}$ month $^{-1}$ level. Two special regions of interest, with low emission levels in general, were revealed by the OMI observations, in the northeast and the southwest of the domain, and are examined in the third and fourth panels, respectively. The first 3 months of the year 2010 in the a posteriori emission database show quite higher levels than the MEIC v1.2 compilation, whereas the rest of the months show the same level for the NE (Fig. 6c), whereas in the SE (Fig. 6d) the first months of the year have an increased $\mathrm{SO}_{2}$ emitting signature.

\subsection{Comparison with existing emission inventories}

Apart from the MEIC v1.2 emission inventory discussed in Sect. 2.1 - which is currently publicly available for the years 2008, 2010 and 2012 - there exist other emission inventories that are frequently used in chemical transport models as input: the Regional Emission inventory in Asia (REAS) v2.1 (Kurokawa et al., 2013); the 2006 Asia Emissions for INTEX-B (Zhang et al., 2009); and the Emissions Database for Global Atmospheric Research, EDGAR v4.3.1 (Crippa et al., 2016). Comparing with similar published works is not as straightforward as one would assume since in this work a sub-domain of what is termed China in other publications is used. For example when calculating the total annual $\mathrm{SO}_{2}$ emissions reported by the REASv2.1 database for the year 2000 , those are found to be $25.62 \mathrm{Tg}$ annum ${ }^{-1}$ when allowing the entire domain provided in the database; they 
Table 1. The average $\mathrm{SO}_{2}$ emission levels over China for the four seasons of the year 2010 as presented in Fig. 5.

\begin{tabular}{lrrrrrr}
\hline & $\begin{array}{r}\text { A priori } \\
{\left[\text { Gg season }^{-1}\right]}\end{array}$ & $\begin{array}{r}\text { A priori error } \\
{\left[\text { Gg season }^{-1}\right]}\end{array}$ & $\begin{array}{r}\text { A posteriori } \\
{\left[\text { Gg season }^{-1}\right]}\end{array}$ & $\begin{array}{r}\text { A posteriori error } \\
{\left[\text { Gg season }^{-1}\right]}\end{array}$ & \# cells & $\%$ difference \\
\hline Spring & 6.36 & 0.135 & 7.77 & 1.57 & 6975 & $18.0(24.0)$ \\
Summer & 5.96 & 0.132 & 6.46 & 1.01 & 5765 & $8.0(14.0)$ \\
Autumn & 6.77 & 0.137 & 7.68 & 1.40 & 7126 & $13.0(20.0)$ \\
Winter & 7.07 & 0.140 & 9.12 & 2.66 & 7254 & $29.0(34.0)$ \\
\hline
\end{tabular}

Table 2. Details of the existing emission databases used for comparative purposes.

\begin{tabular}{|c|c|c|c|c|c|}
\hline Database & $\begin{array}{l}\text { Years } \\
\text { available }\end{array}$ & Spatial resolution & $\begin{array}{l}\text { Temporal } \\
\text { resolution }\end{array}$ & Main reference & Publicly available from: \\
\hline REASv2.1 & $\begin{array}{l}2000 \text { to } \\
2008\end{array}$ & $0.25^{\circ} \times 0.25^{\circ}$ & monthly & Kurokawa et al. (2013) & $\begin{array}{l}\text { https://www.nies.go.jp/REAS/ } \\
\text { (last access: } 20 \text { March 2018) }\end{array}$ \\
\hline INTEX-B & 2006 & $0.5^{\circ} \times 0.5^{\circ}$ & yearly & Zhang et al. (2009) & $\begin{array}{l}\text { https://cgrer.uiowa.edu/projects/emmison-data } \\
\text { (last access: } 20 \text { March 2018) }\end{array}$ \\
\hline EDGAR v4.3.1 & 2010 & $0.1^{\circ} \times 0.1^{\circ}$ & monthly & Crippa et al. (2016) & $\begin{array}{l}\text { http://edgar.jrc.ec.europa.eu/ } \\
\text { (last access: } 20 \text { March 2018) }\end{array}$ \\
\hline
\end{tabular}

are found to be only $15.86 \mathrm{Tg}_{\mathrm{gnnum}}^{-1}$ when restricting in the domain we are studying. As a result, large differences and erroneous comparisons may be presented if one simply compares emissions estimates as reported in published works. For similar comparative studies, we refer the interested reader to Table 3 of Lu et al. (2010) and Table 8 of Kurokawa et al. (2013); however great care is needed when quoting absolute $\mathrm{SO}_{2}$ emission levels.

In Table 2 the details of the three databases are given. Since we are interested in evaluating the $\mathrm{SO}_{2}$ emission as spatial patterns and not point source levels, we focused on these three databases, which are provided at actual spatiotemporal resolutions. As a first inspection, in Table 3, the annual $\mathrm{SO}_{2}$ emissions for the domain $15-50^{\circ} \mathrm{N}, 102-132^{\circ} \mathrm{E}$ in teragrams per year are presented. We should point out that, due to the fact that our methodology is based on the MEIC v1.2 emission inventory, within the domain stated there are large areas with no emissions, mostly over the sea and the Korean Peninsula. In the following comparisons, only the common pixels between all inventories are used for the calculations.

Several issues arise; firstly, for the common years between this work and the REAS v2.1, i.e. 2005 to 2008 , the differences span between $\sim 30$ and $\sim 60 \%$, with REAS v2.1 underestimating the emission levels in the domain studied. For the one common year between REAS v2.1 and MEIC v1.2, namely 2008, this underestimation still holds but is smaller, of the order of $\sim 10 \%$. Similarly, for the one common year between REAS v2.1 and INTEX-B, namely 2006, REAS v2.1 underestimates by $\sim 30 \%$. All of this points to an underestimation of $\mathrm{SO}_{2}$ levels in the domain considered by the REAS v2.1 database.

Comparing the 2006 INTEX-B emissions to the ones calculated in this work, we find a difference of the or- der of $\sim 10 \%$, whereas comparing to the 2010 EDGAR v4.3.1 emissions the difference is almost insignificant, at $\sim 3.5 \%$. Since the EGDAR v4.3.1 emissions are provided on a monthly basis, in contrast to the INTEX-B ones, we can evaluate our spatial patterns as well. After regridding the EDGAR v4.3.1 emissions at a $0.25^{\circ} \times 0.25^{\circ}$ spatial resolution on a monthly basis, the seasonal variability of the inventory is compared to the one presented in this work in Fig. 7.

\section{Summary}

In this work, an updated $\mathrm{SO}_{2}$ emission inventory based on OMI/Aura observations and the CHIMERE v2013b simulations has been presented for the years 2005 to 2015, as part of the EU Seventh Framework Programme (FP7) MarcoPolo (Monitoring and Assessment of Regional air quality in China using space Observations) project, which provides updated emissions over China based on satellite observations of key air quality species. For the domain of $15-50^{\circ} \mathrm{N}$, $102-132^{\circ} \mathrm{E}$ it was shown that the annual $\mathrm{SO}_{2}$ emissions calculated remain stable at $36.0 \pm 1.0 \mathrm{Tg}$ annum $^{-1}$ between 2005 and 2008; decrease to $32 \pm 0.8 \mathrm{Tg}$ annum $^{-1}$ between 2008 and 20103; and reach a low of $\sim 23.0 \mathrm{Tg}^{-1}$ annum $^{-1}$ in 2015 , with highs during the winter months and lows during the spring and summertime. Trend analysis performed on the monthly mean spatial averages shows that pre-2010 the monthly $\mathrm{SO}_{2}$ emissions were $\sim 3.0 \pm 1.0 \mathrm{Tg}$ month $^{-1}$, whereas the statistically significant decrease in the post- 2010 era rises to $-1.52 \pm 0.36 \mathrm{Tg}$. The higher differences to the original a priori MEIC v1.2 2010 inventory were found for the winter months, especially February, with seasonal differences of the order of $\sim 40 \%$ and the smallest for the summer months at $\sim 10 \%$. Comparisons with completely inde- 
Table 3. Annual $\mathrm{SO}_{2}$ emissions over the domain $15-50^{\circ} \mathrm{N}, 102-132^{\circ} \mathrm{E}$ in teragrams per year. First column, the year; second column, this work; third column, the REASv2.1; fourth column, EDGAR v4.3.1; and fifth column, the INTEX-B database.

\begin{tabular}{|c|c|c|c|c|c|}
\hline Year & This work & REASv2.1 & MEIC v1.2 & EDGAR v4.3.1 & INTEX-B \\
\hline & \multicolumn{5}{|c|}{$\mathrm{Tg}$ annum ${ }^{-1}$ for the $15-50^{\circ} \mathrm{N}, 102-132^{\circ} \mathrm{E}$ domain } \\
\hline 2000 & & 15.86 & & & \\
\hline 2001 & & 15.94 & & & \\
\hline 2002 & & 17.53 & & & \\
\hline 2003 & & 19.70 & & & \\
\hline 2004 & & 21.77 & & & \\
\hline 2005 & $35.27 \pm 1.75$ & 24.68 & & & \\
\hline 2006 & $35.33 \pm 1.76$ & 24.45 & & & 32.08 \\
\hline 2007 & $37.58 \pm 1.76$ & 24.40 & & & \\
\hline 2008 & $35.75 \pm 1.76$ & 26.96 & 29.80 & & \\
\hline 2009 & $31.74 \pm 1.75$ & & & & \\
\hline 2010 & $32.14 \pm 1.74$ & & 26.26 & 33.34 & \\
\hline 2011 & $33.50 \pm 1.75$ & & & & \\
\hline 2012 & $31.30 \pm 1.75$ & & 26.48 & & \\
\hline 2013 & $32.05 \pm 1.74$ & & & & \\
\hline 2014 & $28.32 \pm 1.72$ & & & & \\
\hline 2015 & $23.34 \pm 1.71$ & & & & \\
\hline
\end{tabular}

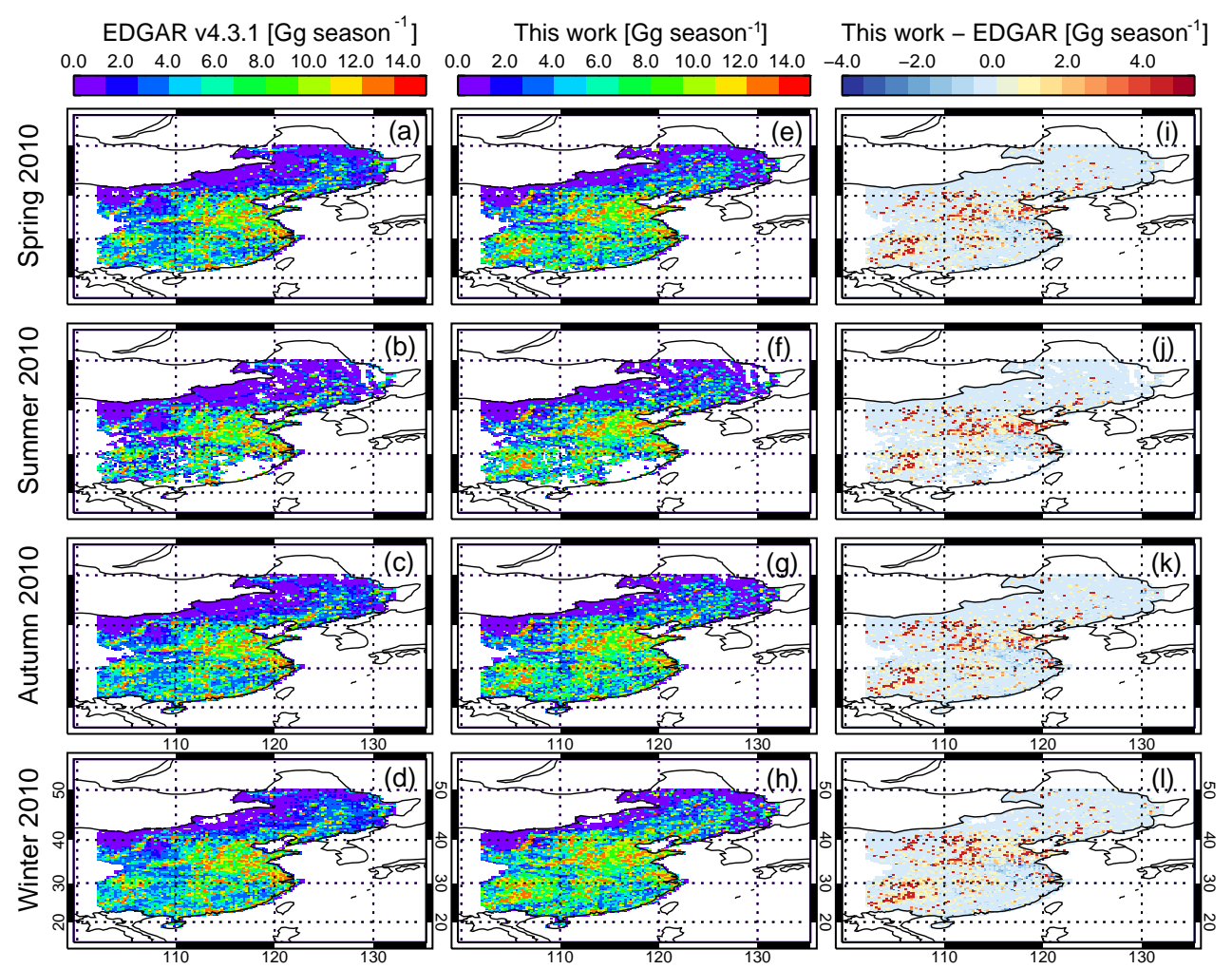

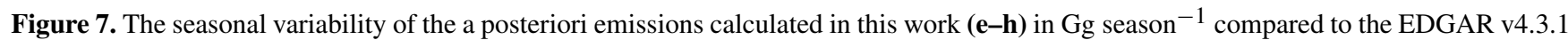
emissions (a-d) in $\mathrm{Gg}$ season ${ }^{-1}$ as well as their absolute differences (i-l). From top to bottom; spring, summer, autumn and winter of the reference year 2010 . 
pendent emission inventories show a good agreement to the 2010 EDGAR v4.3.1 emissions at the 3.5\% level, whereas moderate agreement was found against the 2006 INTEX-B database at the $\sim 10 \%$ level.

The subsequent logical step in this work is to employ the new emission inventory as input information for a chemistry transport model so as to assess the effect of the updated $\mathrm{SO}_{2}$ emissions on the output simulations, as well as validation against independent sources of information on the point sources of $\mathrm{SO}_{2}$ around China, a work under development.

\section{Data availability. Input datasets:}

The OMI/Aura SO2 BIRA dataset and algorithm are described in Theys et al. (2015). The CHIMERE v2013b simulations have been presented in Ding et al. (2015).

Output datasets:

EU FP7 MarcoPolo $\mathrm{SO}_{2}$ emission inventory is publicly available from https://doi.org/10.5281/zenodo.1205329 (Koukouli et al., 2018).

Auxiliary datasets:

The MEIC v1.2 database is publicly available from http://www. meicmodel.org/ (Li et al., 2017).

The INTEX-B database is publicly available from https://cgrer. uiowa.edu/projects/emmison-data (last access: 20 March 2018) (Zhang et al., 2009).

The EDGAR v4.3.1 database is publicly available from http:// edgar.jrc.ec.europa.eu/ (last access: 20 March 2018) (Crippa et al., 2016).

The REAS v2.1 database is publicly available from https://www. nies.go.jp/REAS/ (last access: 20 March 2018) (Kurokawa et al., 2013).

Competing interests. The authors declare that they have no conflict of interest.

Acknowledgements. This work has been funded by the EU FP7 MarcoPolo project, www.marcopolo.eu (last access: 20 March 2018), 2014-2017. Results presented in this work have been produced using the European Grid Infrastructure (EGI) through the National Grid Infrastructures NGI_GRNET (HellasGrid) as part of the SEE Virtual Organization. The authors would like to acknowledge the support provided by the Scientific Computing Office, IT A.U.Th., throughout the progress of this research work. We wholeheartedly thank Eleni Katragkou for her assistance with the ERA-Interim datasets.

Edited by: Ilse Aben

Reviewed by: two anonymous referees

\section{References}

Bauduin, S., Clarisse, L., Hadji-Lazaro, J., Theys, N., Clerbaux, C., and Coheur, P.-F.: Retrieval of near-surface sulfur dioxide $\left(\mathrm{SO}_{2}\right)$ concentrations at a global scale using IASI satellite observations,
Atmos. Meas. Tech., 9, 721-740, https://doi.org/10.5194/amt-9721-2016, 2016.

Boersma, K. F., Jacob, D. J., Eskes, H. J., Pinder, R. W., Wang, J., and van der A, R. J.: Intercomparison of SCIAMACHY and OMI tropospheric $\mathrm{NO}_{2}$ columns: observing the diurnal evolution of chemistry and emissions from space, J. Geophys. Res. 113, D16S26, https://doi.org/10.1029/2007JD008816, 2008a.

Boersma, K. F., Jacob, D. J., Bucsela, E. J., Perring, A. E., Dirksen, R., van der A, R. J., Yantosca, R. M., Park, R. J., Wenig, M. O., Bertram, T. H., and Cohen, R. C.: Validation of OMI tropospheric NO observations during INTEX$\mathrm{B}$ and application to constrain emissions over the eastern United States and Mexico, Atmos. Environ., 42, 4480-4497, https://doi.org/10.1016/j.atmosenv.2008.02.004, 2008b.

Boersma, K. F., Vinken, G. C. M., and Eskes, H. J.: Representativeness errors in comparing chemistry transport and chemistry climate models with satellite UV-Vis tropospheric column retrievals, Geosci. Model Dev., 9, 875-898, https://doi.org/10.5194/gmd-9-875-2016, 2016.

Ceccherini, S. and Ridolfi, M.: Technical Note: Variance-covariance matrix and averaging kernels for the Levenberg-Marquardt solution of the retrieval of atmospheric vertical profiles, Atmos. Chem. Phys., 10, 3131-3139, https://doi.org/10.5194/acp-103131-2010, 2010.

Cooper, M., Martin, R. V., Padmanabhan, A., and Henze, D. K.: Comparing mass balance and adjoint methods for inverse modeling of nitrogen dioxide columns for global nitrogen oxide emissions, J. Geophys. Res.-Atmos., 122, 4718-4734, https://doi.org/10.1002/2016JD025985, 2017.

Crippa, M., Janssens-Maenhout, G., Dentener, F., Guizzardi, D. Sindelarova, K., Muntean, M., Van Dingenen, R., and Granier, C.: Forty years of improvements in European air quality: regional policy-industry interactions with global impacts, Atmos. Chem. Phys., 16, 3825-3841, https://doi.org/10.5194/acp16-3825-2016, 2016.

Dee, D. P., Uppala, S. M., Simmons, A. J., Berrisford, P., Poli, P., Kobayashi, S., Andrae, U., Balmaseda, M. A., Balsamo, G., Bauer, P., Bechtold, P., Beljaars, A. C. M., van de Berg, L., Bidlot, J., Bormann, N., Delsol, C., Dragani, R., Fuentes, M., Geer, A. J., Haimberger, L., Healy, S. B., Hersbach, H., Hólm, E. V., Isaksen, L., Kållberg, P., Köhler, M., Matricardi, M., McNally, A. P., Monge-Sanz, B. M., Morcrette, J.-J., Park, B.K., Peubey, C., de Rosnay, P., Tavolato, C., Thépaut, J.-N., and Vitart, F.: The ERA-Interim reanalysis: configuration and performance of the data assimilation system, Q. J. Roy. Meteor. Soc. 137, 553-597, https://doi.org/10.1002/qj.828, 2011.

Deguillaume, L., Beekmann, M., and Derognat, C.: Uncertainty evaluation of ozone production and its sensitivity to emission changes over the Ile-de-France region during summer periods, J. Geophys. Res., 113, D02304, https://doi.org/10.1029/2007JD009081, 2008.

Ding, J., van der A, R. J., Mijling, B., Levelt, P. F., and Hao, N.: $\mathrm{NO}_{x}$ emission estimates during the 2014 Youth Olympic Games in Nanjing, Atmos. Chem. Phys., 15, 93999412, https://doi.org/10.5194/acp-15-9399-2015, 2015.

Eskes, H. J. and Boersma, K. F.: Averaging kernels for DOAS totalcolumn satellite retrievals, Atmos. Chem. Phys., 3, 1285-1291, https://doi.org/10.5194/acp-3-1285-2003, 2003. 
Fioletov, V. E., McLinden, C. A., Krotkov, N., Yang, K., Loyola, D. G., Valks, P., Theys, N., Van Roozendael, M., Nowlan, C. R., Chance, K., Liu, X., Lee, C., and Martin, R. V.: Application of OMI, SCIAMACHY, and GOME-2 satellite $\mathrm{SO}_{2}$ retrievals for detection of large emission sources, J. Geophys. Res.-Atmos., 118, 11399-11418, https://doi.org/10.1002/jgrd.50826, 2013.

Fioletov, V. E., McLinden, C. A., Krotkov, N., and Li, C.: Lifetimes and emissions of $\mathrm{SO}_{2}$ from point sources estimated from OMI, Geophys. Res. Lett., 42, 1969-1976, https://doi.org/10.1002/2015GL063148, 2015.

Fioletov, V. E., McLinden, C. A., Krotkov, N., Li, C., Joiner, J., Theys, N., Carn, S., and Moran, M. D.: A global catalogue of large $\mathrm{SO}_{2}$ sources and emissions derived from the Ozone Monitoring Instrument, Atmos. Chem. Phys., 16, 11497-11519, https://doi.org/10.5194/acp-16-11497-2016, 2016.

Fioletov, V., McLinden, C. A., Kharol, S. K., Krotkov, N. A., Li, C., Joiner, J., Moran, M. D., Vet, R., Visschedijk, A. J. H., and Denier van der Gon, H. A. C.: Multi-source $\mathrm{SO}_{2}$ emission retrievals and consistency of satellite and surface measurements with reported emissions, Atmos. Chem. Phys., 17, 12597-12616, https://doi.org/10.5194/acp-17-12597-2017, 2017.

Gu, D., Wang, Y., Smeltzer, C., and Boersma, K. F.: Anthropogenic emissions of $\mathrm{NO}_{x}$ over China: reconciling the difference of inverse modeling results using GOME-2 and OMI measurements, J. Geophys. Res.-Atmos., 119, 7732-7740, https://doi.org/10.1002/2014JD021644, 2014.

Hains, J. C., Tabumann, B. F., Thompson, A. M., Stehr, J. W., Marufu, L. T., Doddridge, B. G., and Dickerson, R. R.: Origins of chemical pollution derived from mid-Atlantic aircraft profiles using a clustering technique, Atmos. Environ., 42, 1727-1741, https://doi.org/10.1016/j.atmosenv.2007.11.052, 2008.

Jiang, J., Zha, Y., Gao, J., and Jiang, J.: Monitoring of $\mathrm{SO}_{2}$ column concentration change over China from Aura OMI data, Int. J. Remote Sens., 33, 1934-1942, https://doi.org/10.1080/01431161.2011.603380, 2012.

Kan, H., Chen, R., and Tong, S.: Ambient air pollution, climate change, and population health in China, Environ. Int., 42, 10-19, https://doi.org/10.1016/j.envint.2011.03.003, 2012.

Klimont, Z., Smith, S. J., and Cofala, J.: The last decade of global anthropogenic sulphur dioxide: 2000-2011 emissions, Environ. Res. Lett., 8, 014003, https://doi.org/10.1088/17489326/8/1/014003, 2013.

Koukouli, M. E., Balis, D. S., van der A, R., Theys, N., Hedelt, P., Richter, A., Krotkov, N., Li, C., and Taylor, M.: Anthropogenic sulphur dioxide load over China as observed from different satellite sensors, Atmos. Environ., 145, 45-59, https://doi.org/10.1016/j.atmosenv.2016.09.007, 2016.

Koukouli, M. E., Theys, N., Ding, J., Zyrichidou, I., Mijling, B., Balis, D., and van der A, R.: EU MarcoPolo project|SO $\mathrm{SO}_{2}$ emission inventory over China (Version v0.1), Zenodo. https://doi.org/10.5281/zenodo.1205329, 2018.

Krotkov, N. A., McLinden, C. A., Li, C., Lamsal, L. N., Celarier, E. A., Marchenko, S. V., Swartz, W. H., Bucsela, E. J., Joiner, J., Duncan, B. N., Boersma, K. F., Veefkind, J. P., Levelt, P. F., Fioletov, V. E., Dickerson, R. R., He, H., Lu, Z., and Streets, D. G.: Aura OMI observations of regional $\mathrm{SO}_{2}$ and $\mathrm{NO}_{2}$ pollution changes from 2005 to 2015, Atmos. Chem. Phys., 16, 4605-4629, https://doi.org/10.5194/acp-16-4605-2016, 2016.
Kurokawa, J., Ohara, T., Morikawa, T., Hanayama, S., JanssensMaenhout, G., Fukui, T., Kawashima, K., and Akimoto, H.: Emissions of air pollutants and greenhouse gases over Asian regions during 2000-2008: Regional Emission inventory in ASia (REAS) version 2, Atmos. Chem. Phys., 13, 11019-11058, https://doi.org/10.5194/acp-13-11019-2013, 2013.

Lamsal, L. N., Martin, R. V., van Donkelaar, A., Celarier, E. A., Bucsela, E. J., Boersma, K. F., Dirksen, R., Luo, C., and Wang, Y.: Indirect validation of tropospheric nitrogen dioxide retrieved from the OMI satellite instrument: insight into the seasonal variation of nitrogen oxides at northern midlatitudes, J. Geophys. Res., 115, D05302, https://doi.org/10.1029/2009JD013351, 2010.

Lee, C., Martin, R. V., van Donkelaar, A., O’Byrne, G., Krotkov, N., Richter, A., Huey, L. G., and Holloway, J. S.: Retrieval of vertical columns of sulphur dioxide from SCIAMACHY and OMI: air mass factor algorithm development, validation, and error analysis, J. Geophys. Res., 114, D22303, https://doi.org/10.1029/2009JD012123, 2009.

Lee, C., Martin, R. V., van Donkelaar, A., Lee, H., Dickerson, R. R., Hains, J. C., Krotkov, N., Richter, A., Vinnikov, K., and Schwab, J. J.: $\mathrm{SO}_{2}$ emissions and lifetimes: estimates from inverse modeling using in situ and global, space-based (SCIAMACHY and OMI) observations, J. Geophys. Res., 116, D06304, https://doi.org/10.1029/2010JD014758, 2011.

Leue, C., Wenig, M., Wagner, T., Klimm, O., Platt, U., and Jähne, B.: Quantitative analysis of $\mathrm{NO}_{x}$ emissions from Global Ozone Monitoring Experiment satellite image sequences, J. Geophys. Res., 106, 5493-5505, https://doi.org/10.1029/2000JD900572, 2001.

Levelt, R. F., van den Oord, G. H. J., Dobber, M. R., Malkki, A., Visser, H., de Vries, J., Stammes, P., Lundell, J. O. V., and Saari, H.: The ozone monitoring instrument, IEEE T. Geosc. Remote, 44, 1093-1101, https://doi.org/10.1109/TGRS.2006.872333, 2006.

Li, C., Zhang, Q., Krotkov, N. A., Streets, D. G., He, K., Tsay, S.C., and Gleason, J. F.: Recent large reduction in sulphur dioxide emissions from Chinese power plants observed by the Ozone Monitoring Instrument, Geophys. Res. Lett., 37, L08807, https://doi.org/10.1029/2010GL042594, 2010.

Li, M., Zhang, Q., Kurokawa, J.-I., Woo, J.-H., He, K., Lu, Z., Ohara, T., Song, Y., Streets, D. G., Carmichael, G. R., Cheng, Y., Hong, C., Huo, H., Jiang, X., Kang, S., Liu, F., Su, H., and Zheng, B.: MIX: a mosaic Asian anthropogenic emission inventory under the international collaboration framework of the MICS-Asia and HTAP, Atmos. Chem. Phys., 17, 935-963, https://doi.org/10.5194/acp-17-935-2017, 2017.

Lin, J.-T., McElroy, M. B., and Boersma, K. F.: Constraint of anthropogenic $\mathrm{NO}_{x}$ emissions in China from different sectors: a new methodology using multiple satellite retrievals, Atmos. Chem. Phys., 10, 63-78, https://doi.org/10.5194/acp-10-632010, 2010.

Liu, F., Zhang, Q., Tong, D., Zheng, B., Li, M., Huo, H., and He, K. B.: High-resolution inventory of technologies, activities, and emissions of coal-fired power plants in China from 1990 to 2010, Atmos. Chem. Phys., 15, 13299-13317, https://doi.org/10.5194/acp-15-13299-2015, 2015.

Liu, F., Zhang, Q., van der A, R. J., Zheng, B., Tong, D., Yan, L., Zheng, Y., and He, K.: Recent reduction in 
$\mathrm{NO}_{x}$ emissions over China: synthesis of satellite observations and emission inventories, Environ. Res. Lett., 11, 114002, https://doi.org/10.1088/1748-9326/11/11/114002, 2017.

Feng, L. and Liao, W.: Legislation, plans, and policies for prevention and control of air pollution in China: achievements, challenges, and improvements, J. Clean. Prod., 112, 1549-1558, https://doi.org/10.1016/j.jclepro.2015.08.013, 2016.

Lu, Z., Streets, D. G., Zhang, Q., Wang, S., Carmichael, G. R., Cheng, Y. F., Wei, C., Chin, M., Diehl, T., and Tan, Q.: Sulfur dioxide emissions in China and sulfur trends in East Asia since 2000, Atmos. Chem. Phys., 10, 6311-6331, https://doi.org/10.5194/acp-10-6311-2010, 2010.

Lu, Z., Zhang, Q., and Streets, D. G.: Sulfur dioxide and primary carbonaceous aerosol emissions in China and India, 1996-2010, Atmos. Chem. Phys., 11, 9839-9864, https://doi.org/10.5194/acp-11-9839-2011, 2011.

Martin, R. V., Jacob, D. J., Chance, K., Kurosu, T. P., Palmer, P. I., and Evans, M. J.: Global inventory of nitrogen oxide emissions constrained by space-based observations of $\mathrm{NO}_{2}$ columns, J. Geophys. Res., 108, 4537, https://doi.org/10.1029/2003JD003453, 2003.

Martin, R. V., Sioris, C. E., Chance, K., Ryerson, T. B., Bertram, T. H., Wooldridge, P. J., Cohen, R. C., Neuman, J. A., Swanson, A., and Flocke, F. M.: Evaluation of space-based constraints on global nitrogen oxide emissions with regional aircraft measurements over and downwind of eastern North America, J. Geophys. Res., 111, D15308, https://doi.org/10.1029/2005JD006680, 2006.

Menut, L., Bessagnet, B., Khvorostyanov, D., Beekmann, M., Blond, N., Colette, A., Coll, I., Curci, G., Foret, G., Hodzic, A., Mailler, S., Meleux, F., Monge, J.-L., Pison, I., Siour, G., Turquety, S., Valari, M., Vautard, R., and Vivanco, M. G.: CHIMERE 2013: a model for regional atmospheric composition modelling, Geosci. Model Dev., 6, 9811028, https://doi.org/10.5194/gmd-6-981-2013, 2013.

Mijling, B. and van der A, R. J.: Using daily satellite observations to estimate emissions of short-lived air pollutants on a mesoscopic scale, J. Geophys. Res., 117, D17302, https://doi.org/10.1029/2012JD017817, 2012.

Pirovano, G., Balzarini, A., Bessagnet, B., Emery, C., Kallos, G., Meleux, F., Mitsakou, C., Nopmongcol, U., Riva, G. M., and Yarwood, G.: Investigating impacts of chemistry and transport model formulation on model performance at European scale, Atmos. Environ., 53, 93-109, https://doi.org/10.1016/j.atmosenv.2011.12.052, 2012.

Platt, U. and Stutz, J.: Differential Absorption Spectroscopy: Principles and Applications, Berlin-Heidelberg: Springer-Verlag, https://doi.org/10.1007/978-3-540-75776-4, 2008.

Rodgers, C. D.: Inverse Methods for Atmospheric Sounding: Theory and Practice, World Sci., Hackensack, NJ, 2000.

Schmidt, A., Leadbetter, S., Theys, N., Carboni, E., Witham, C. S., Stevenson, J. A., Birch, C. E., Thordarson, T., Turnock, S., Barsotti, S., Delaney, L., Feng, W., Grainger, R. G., Hort, M. C., Höskuldsson, A., Ialongo, I., Ilyinskaya, E., Jóhannsson, T., Kenny, P., Mather, T. A., Richards, N. A. D., and Shepherd, J.: Satellite detection, long-range transport, and air quality impacts of volcanic sulphur dioxide from the 2014-2015 flood lava eruption at Bárðarbunga (Iceland), J. Geophys. Res.-Atmos., 120, 9739-9757, https://doi.org/10.1002/2015JD023638, 2015.
Seinfeld, J. H. and Pandis, S. N.: Atmospheric Chemistry and Physics: From Air Pollution to Climate Change, John Wiley and Sons, University of Michigan, 1998.

Smith, S. J., Pitcher, H., and Wigley, T. M. L.: Global and regional anthropogenic sulphur dioxide emissions, Global Planet. Change, 29, 99-119, https://doi.org/10.1016/S09218181(00)00057-6, 2001.

Smith, S. J., van Aardenne, J., Klimont, Z., Andres, R. J., Volke, A., and Delgado Arias, S.: Anthropogenic sulfur dioxide emissions: 1850-2005, Atmos. Chem. Phys., 11, 1101-1116, https://doi.org/10.5194/acp-11-1101-2011, 2011.

Song, C., Wu, L., Xie, Y., He, J., Chen, X., Wang, T., Lin, Y., Jin, T., Wang, A., Liu, Y., Dai, Q., Liu, B., Wang, Y., and Mao, H.: Air pollution in China: status and spatiotemporal variations, Environ. Pollut., 227, 334-347, https://doi.org/10.1016/j.envpol.2017.04.075, 2017.

Stavrakou, T., Müller, J.-F., Boersma, K. F., van der A, R. J., Kurokawa, J., Ohara, T., and Zhang, Q.: Key chemical $\mathrm{NO}_{x}$ sink uncertainties and how they influence top-down emissions of nitrogen oxides, Atmos. Chem. Phys., 13, 9057-9082, https://doi.org/10.5194/acp-13-9057-2013, 2013.

Streets, D. G., Canty, T., Carmichael, G. R., de Foy, B., Dickerson, R. R., Duncan, B. N., Edwards, D. P., Haynes, J. A., Henze, D. K., Houyoux, M. R., Jacob, D. J., Krotkov, N. A., Lamsal, L. N., Liu, Y., Lu, Z., Martin, R. V., Pfister, G. G., Pinder, R. W., Salawitch, R. J., and Wecht, K. J.: Emissions estimation from satellite retrievals: a review of current capability, Atmos. Environ., 77, 1011-1042, https://doi.org/10.1016/j.atmosenv.2013.05.051, 2013.

Theys, N., De Smedt, I., van Gent, J., Danckaert, T., Wang, T., Hendrick, F., Stavrakou, T., Bauduin, S., Clarisse, L., Li, C., Krotkov, N., Yu, H., Brenot, H., and Van Roozendael, M.: Sulphur dioxide vertical column DOAS retrievals from the Ozone Monitoring Instrument: global observations and comparison to groundbased and satellite data, J. Geophys. Res.-Atmos., 120, 2470 2491, https://doi.org/10.1002/2014JD022657, 2015.

Theys, N., De Smedt, I., Yu, H., Danckaert, T., van Gent, J., Hörmann, C., Wagner, T., Hedelt, P., Bauer, H., Romahn, F., Pedergnana, M., Loyola, D., and Van Roozendael, M.: Sulfur dioxide retrievals from TROPOMI onboard Sentinel-5 Precursor: algorithm theoretical basis, Atmos. Meas. Tech., 10, 119-153, https://doi.org/10.5194/amt-10-119-2017, 2017.

van $\operatorname{der}$ A, R. J., Mijling, B., Ding, J., Koukouli, M. E., Liu, F., Li, Q., Mao, H., and Theys, N.: Cleaning up the air: effectiveness of air quality policy for $\mathrm{SO}_{2}$ and $\mathrm{NO}_{x}$ emissions in China, Atmos. Chem. Phys., 17, 1775-1789, https://doi.org/10.5194/acp17-1775-2017, 2017.

Wang, S., Streets, D. G., Zhang, Q., He, K., Chen, D., Kang, S., Lu, Z., and Wang, Y.: Satellite detection and model verification of $\mathrm{NO}_{x}$ emissions from power plants in Northern China, Environ. Res. Lett., 5, 044007, https://doi.org/10.1088/17489326/5/4/044007, 2010.

Wang, S., Zhang, Q., Martin, R. V., Philip, S., Liu, F., Li, M., Jiang, X., and He, K.: Satellite measurements oversee China's sulphur dioxide emission reductions from coal-fired power plants, Environ. Res. Lett., 10, 114015, https://doi.org/10.1088/17489326/10/11/114015, 2015.

Wang, Y., Beirle, S., Lampel, J., Koukouli, M., De Smedt, I., Theys, N., Li, A., Wu, D., Xie, P., Liu, C., Van Roozendael, M., 
Stavrakou, T., Müller, J.-F., and Wagner, T.: Validation of OMI, GOME-2A and GOME-2B tropospheric $\mathrm{NO}_{2}, \mathrm{SO}_{2}$ and $\mathrm{HCHO}$ products using MAX-DOAS observations from 2011 to 2014 in Wuxi, China: investigation of the effects of priori profiles and aerosols on the satellite products, Atmos. Chem. Phys., 17, 50075033, https://doi.org/10.5194/acp-17-5007-2017, 2017.

Witte, J. C., Schoeberl, M. R., Douglass, A. R., Gleason, J. F., Krotkov, N. A., Gille, J. C., Pickering, K. E., and Livesey, N.: Satellite observations of changes in air quality during the 2008 Beijing Olympics and Paralympics, Geophys. Res. Lett., 36, L17803, https://doi.org/10.1029/2009GL039236, 2009.

Zhang, L., Jacob, D. J., Liu, X., Logan, J. A., Chance, K., Eldering, A., and Bojkov, B. R.: Intercomparison methods for satellite measurements of atmospheric composition: application to tropospheric ozone from TES and OMI, Atmos. Chem. Phys., 10, 4725-4739, https://doi.org/10.5194/acp-10-4725-2010, 2010.

Zhang, Q., Streets, D. G., Carmichael, G. R., He, K. B., Huo, H., Kannari, A., Klimont, Z., Park, I. S., Reddy, S., Fu, J. S., Chen, D., Duan, L., Lei, Y., Wang, L. T., and Yao, Z. L.: Asian emissions in 2006 for the NASA INTEX-B mission, Atmos. Chem. Phys., 9, 5131-5153, https://doi.org/10.5194/acp-9-51312009, 2009.
Zhang, Q., He, K., and Huo, H.: Cleaning China's air, Nature, 484, 161-162, https://doi.org/10.1038/484161a, 2012.

Zhang, Q. Q., Wang, Y., Ma, Q., Yao, Y., Xie, Y., and He, K.: Regional differences in Chinese $\mathrm{SO}_{2}$ emission control efficiency and policy implications, Atmos. Chem. Phys., 15, 6521-6533, https://doi.org/10.5194/acp-15-6521-2015, 2015.

Zhou, Y., Brunner, D., Boersma, K. F., Dirksen, R., and Wang, P.: An improved tropospheric $\mathrm{NO}_{2}$ retrieval for OMI observations in the vicinity of mountainous terrain, Atmos. Meas. Tech., 2, 401-416, https://doi.org/10.5194/amt-2-401-2009, 2009.

Zyrichidou, I., Koukouli, M. E., Balis, D., Markakis, K., Poupkou, A., Katragkou, E., Kioutsioukis, I., Melas, D., Boersma, K. F., and van Roozendael, M.: Identification of surface NO emission sources on a regional scale using OMI NO, Atmos. Environ., 101, 82-93, https://doi.org/10.1016/j.atmosenv.2014.11.023>, 2015. 